\title{
Mapping of MoMA and the Current Philippine Cinema
}

Richard Bolisay

An exhibition of modern Filipino cinema was held at the New York Museum of Modern Art (MoMA) in June 2017. "A New Golden Age: Contemporary Philippine Cinema" collected 18 films by 13 Filipino directors; the selection exhibited Filipino independent cinema's "diversity of genre and style, audacious formal experimentation, and multiplicity of personal/social/ political perspectives" (The Museum of Modern Art, 2017). Organized by the MoMA's associate curator La Frances Hui, the exhibit screened movies released from mid-2000s to the 2017, works that belong to and represent the “Third Golden Age of Philippine Cinema." Several directors had more than one film under their names, by virtue of their popularity in the international festival circuit.

This should have been a proud moment for an industry long absent from the political map of world cinema. With the MoMA's prestigious reputation as a cultural institution, the exhibition validates the significance of the recent surge of Filipino films and its independent cinema, and legitimizes a new "golden age" of Philippine cinema. Unfortunately, despite its merits, this exhibition reinforces a prevailing system that foregrounds a type of cinema and ignores another, "unwittingly continuing the promotion of a homogeneous, Manila-centric vision of a Philippine national cinema," as the Cebu-based scholar Paul Grant (2017) puts it. No representation is innocent or apolitical; the exhibit's disregard for a responsible survey of what purports to be contemporary Philippine cinema can have a harmful and irreparable effect on the interpretation of Filipino narratives.

Like most national cinemas, Philippine cinema cannot be fully and fairly represented by one film, one filmmaker, or even by a selection of films. However: foreign critics and those who value their opinions formulate a homogeneous view of a country and its culture from exposure only to films by the same directors being invited to the world's biggest festivals, and championed by their respective patrons. This is not to say that the poverty and crimes shown in Brillante Mendoza's works do not persist in Philippine society, or that the bleak milieu and tortured souls evident in Lav Diaz's stories do not exist. A serious understanding of a national cinema requires going beyond dominant representations, and attempting to see the picture and its scenery, how it was taken, the struggles leading to its creation, and the conditions from which such political art springs.

A quick look at the map of the Philippines reveals much: an archipelago made up of thousands of islands, divided into three big groups (Luzon, 
Visayas, and Mindanao) from north to south. Separated by water and languages, it is a nation whose unifying quality is its diversity. Its national language-Filipino, not Tagalog as often presumed-belies the hundreds of others that are just as rich. With different languages come different stories and histories, each unique, nuanced, and contributing to the national identity. Sadly, not every Philippine language is given the opportunity to be represented its own people.

Majority of film productions and screenings take place in the capital. Manila-based filmmakers and Manila-centric ideologies and narratives have long upheld control and privilege, even though Cebu in Visayas has its own industry and two golden ages (in the 1950s and 1970s). It is no surprise that two of the most prominent Filipino films feature Manila in their titles: Maynila: Sa Mga Kuko ng Liwanag [Manila: In the Claws of Light] by Lino Brocka (1975) and Manila by Night by Ishmael Bernal (1980). These two works are exceptional in their bold critique of living in Manila in the 1970s and 1980s under martial law, and unabashedly unapologetic in their portrayal of a cruel city. The term "imperial Manila" has often been used disparagingly but not unfairly: the logic of asserting an all-inclusive national cinema is defeated by blatant hegemony unfortunately perpetuated on both large and small scales.

Despite the congestion and rampant poverty, Manila has thus become a place to aspire for, a city for dreamers, a melting pot of cultures in which different voices gather and wait for their turn to be heard. The Filipino migrant culture is not only spatial-migrants are compelled by their socioeconomic conditions to chase better opportunities-but also adaptive; migrants incorporate themselves into the present environment without foregoing their roots. For decades, migrants from provinces outside Manila, dissatisfied in their respective fields, take on the bigger challenge of settling in the capital. Some are hopeful actors or singers waiting for their breaks, while some are willing to start from the bottom and work as production assistants to become writers and directors.

Nora Aunor, considered the greatest Filipino actor, hails from Iriga, Camarines Sur. Kidlat Tahimik, regarded as the father of Philippine independent cinema, is from Baguio, Benguet. Brocka, a Cannes favorite, was from Pilar, Sorsogon. Mendoza, another Cannes favorite, is from San Fernando, Pampanga. Diaz, who has won the top prizes from Locarno and Venice, is from Datu Paglas, Maguindanao.

Films produced in Manila, screened in Manila, and the Manila depicted in films do not essentially represent a singular Manila; Filipinos from different parts of the nation, carry different sensibilities and produce a cinema that 
is plural and heterogeneous. This has become a standard definition of Philippine cinema: a dominant industry that welcomes all but does not necessarily include all, a delineation dictated by political geography. In lieu of more accurate alternatives, this definition persists.

People often mistake the early 2000s for the decade that birthed Philippine independent cinema, which had already existed and prospered, albeit on a more modest scale, decades ago. The advent of digital technology prompted the democratization of filmmaking; the 2000s saw a decentralized industry alongside a consistent and diligent commercial cinema which released new movies bimonthly. The growing community took advantage of cheaper equipment and the efficiency of the internet to make films with relative ease. Accessibility and affordability of technology made cinema a more attractive tool for storytelling and encouraged the production of more films of better quality.

The number of independent movies increased along with the number of festivals offering screening venues: Cinemanila, Cinemalaya, and Cinema One Originals. Several filmmakers attended foreign circuits: Khavn dela Cruz, Raya Martin, John Torres, Adolf Alix, Jr., Sherad Anthony Sanchez, Jerrold Tarog, Auraeus Solito, and Alvin Yapan, to name a few Jeffrey Jeturian, Erik Matti, Jose Javier Reyes, Joel Lamangan, Gil Portes, Chito Roño, Raymond Red were some of the directors who had been active for decades who managed to find a new audience.

Filmmakers and their audiences benefitted from the Philippine filmmaking landscape becoming more inclusive. Without undermining other changes, the flurry of activity in the 2000s brought an influx of filmmakers from different parts of Luzon, Visayas, and Mindanao who finally found the opportunity to tell their own stories. There is a huge difference between a Manila filmmaker going to Cebu or Davao and setting a story in these cities and a Cebuano or Davaoeño filmmaker doing the same. More than quality, it is an issue of perspective, sensibility, and a distribution of privilege that ideally diminishes cultural appropriation. The astonishing power of Ang Damgo ni Eleuteria [The Dream of Eleuteria] by Cebuano filmmaker Remton Siega Zuasola (2010) comes from its commitment to telling a complex story in one continuous take-technique reminiscent of the magic of Mababangong Bangungot [Perfumed Nightmare] by Tahimik (1977) - and its externalization and extrapolation of a poor family's desire to have a better life. The premise is distinctly Cebuano and Filipino, and also similar to the situation faced by those living in emerging economies. Ang Paglalakbay ng mga Bituin sa Gabing Madilim [The Journey of Stars during the Dark Night] by Arnel Mardoquio (2012) and Women of the Weeping 
River by Sheron Dayoc (2016) are two of the finest anti-war films ever made, combining a clear political stance with visual poetry, and rendering the decades-long conflict in Mindanao with urgency and wisdom.

The development of the independent cinema has provided the diversity lacking in commercial Philippine cinema, and yielding an array of Filipino directors whose films tackle the complexities of their roots using their own language: Christopher Gozum (Pangasinan), Jason Paul Laxamana (Pampanga), Mes de Guzman (Nueva Vizcaya), Lemuel Lorca (Quezon), Ara Chawdhury (Cebu), Keith Deligero (Cebu), Ray Gibraltar (Iloilo, and Negros Occidental), Gutierrez Mangansakan II (Maguindanao), and Bagane Fiola (Davao). There have also been short films made in languages, including Ilocano, Kankanaey, Bicolano, Waray-Waray, Hiligaynon, Kinaray-a, Higaonon, and Chavacano.

While mainstream cinema continued to produce genre films for profit (comedies, romance, and horror), to recycle tropes, and cater to a traditional view of what the masses would like (values-oriented, dramatic confrontations, happy endings), independent cinema engaged sociopolitical issues long thought unfit for film, subjects considered too serious or depressing to carry entertainment value: human trafficking, street crimes, unemployment, calamities, violence, sexual awakenings, historical reinterpretations, the war in Mindanao, and the death of culture. Independent films situated stories and plots in places too uncommon for general audiences: urban shanties, rural dwellings, maternity wards, public cemeteries, government offices, cul-de sacs, mosques, forests where soldiers and rebels clashed, and remote communities where taboos are exposed.

Although it has its share of missteps and ill-intentioned people, this alternative industry has pushed and rallied for pluralism and achieved it. Independent cinema has represented Philippine cinema visible in international festivals since its last participation in the 1970s and 1980s, two decades of political turmoil. Local audiences, young and old alike, have continued to support it during another period of political instability, by attending bimonthly festivals.

Pronouncements declaring a Third Golden Age of Philippine cinema feel merited because this period of persistence reasonably feels similar to the first two eras that preceded it. Like the 1940-50s and 1970-80s, this era is marked by the production of major works and the proliferation of key ideas, both constructive and problematic.

The dichotomous relationship between commercial and independent cinema was created by substantial arguments deliberating modes of production and abusive practices in production environments, and criticism 
about aesthetic poor technical quality and the ugliness of independent films and the glossiness and fakeness of mainstream movies. The industry thrives in resistance, in the push and pull of ideas, until everyone gets tired and moves on.

The discussion surrounding the term "poverty porn," which describes the representation of poverty with uncomfortable fetishism to pique the attention of foreign programmers whose basic knowledge of the Philippines, though not untrue, is its being a Third World country.

What is the future of Philippine cinema? It is not completely wrong to suggest that there is an uncanny parallelism between the country's political ground and the film industry; Filipinos are motivated by social events to take action and make art that reflects the struggles of present society. As documents of time, films are a tool of memory, connecting the past, present, and future. Films depict the atrocities of the war in Mindanao and martial law, both of which are happening at the time of writing. Films allow audiences to understand how poverty is as omnipresent as the gods, and as powerful in the shaping of peoples' lives. Films offer a space to exercise the freedom fought bloodily against imperialists, and a channel to reinforce the importance of story telling as proof-of-life. If cinema, like real life, is survival of the fittest, then it is one's moral and noble responsibility to do one's best to let others live and help them carry on. 


\section{REFERENCES}

Grant, P. (2017, June). Screening the regions: An incomplete Philippine cinema. Retrieved from http:// brooklynrail.org/2017/06/film/Screening-the-Regions.

The Museum of Modern Art. (2017, June). A new golden age:Contemporary Philippine cinema. Retrieved from https://www.moma.org/calendar/film/3843.

RICHARD BOLISAY is a writer, editor, and film critic based in Manila. His essays on cinema, music, and popular culture have appeared in various local and international publications. He served as a jury member for the Hong Kong International Film Festival, QCinema International Film Festival, and Cinema One Originals Film Festival (corresponding author:themasterspinner@gmail.com). 